\title{
Conceptual model of the industry sector in an energy system model: A case study for
} Denmark

\author{
Wiese, Frauke; Baldini, Mattia
}

Published in:

Journal of Cleaner Production

Link to article, DOI:

10.1016/j.jclepro.2018.08.229

Publication date:

2018

Document Version

Peer reviewed version

Link back to DTU Orbit

Citation (APA):

Wiese, F., \& Baldini, M. (2018). Conceptual model of the industry sector in an energy system model: A case study for Denmark. Journal of Cleaner Production, 203, 427-443. https://doi.org/10.1016/j.jclepro.2018.08.229

\section{General rights}

Copyright and moral rights for the publications made accessible in the public portal are retained by the authors and/or other copyright owners and it is a condition of accessing publications that users recognise and abide by the legal requirements associated with these rights.

- Users may download and print one copy of any publication from the public portal for the purpose of private study or research.

- You may not further distribute the material or use it for any profit-making activity or commercial gain

- You may freely distribute the URL identifying the publication in the public portal 


\section{Accepted Manuscript}

Conceptual model of the industry sector in an energy system model: A case study for Denmark

Frauke Wiese, Mattia Baldini

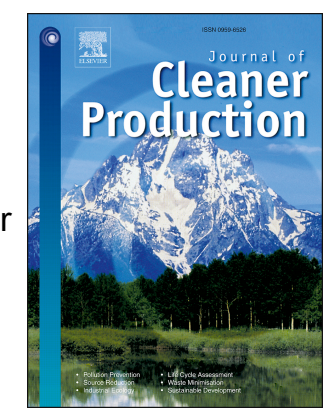

PII:

S0959-6526(18)32578-2

DOI:

10.1016/j.jclepro.2018.08.229

Reference: JCLP 14013

To appear in: Journal of Cleaner Production

Received Date: 27 January 2018

Revised Date: 17 August 2018

Accepted Date: 21 August 2018

Please cite this article as: Wiese F, Baldini M, Conceptual model of the industry sector in an energy system model: A case study for Denmark, Journal of Cleaner Production (2018), doi: 10.1016/ j.jclepro.2018.08.229.

This is a PDF file of an unedited manuscript that has been accepted for publication. As a service to our customers we are providing this early version of the manuscript. The manuscript will undergo copyediting, typesetting, and review of the resulting proof before it is published in its final form. Please note that during the production process errors may be discovered which could affect the content, and all legal disclaimers that apply to the journal pertain. 


\title{
Conceptual model of the industry sector in an energy system model: a case study for Denmark
}

\author{
Frauke Wiese ${ }^{\mathrm{a}}$, Mattia Baldini ${ }^{\mathrm{a},}$, \\ ${ }^{a}$ DTU Management Engineering, Technical University of Denmark \\ *Corresponding author \\ Email address: mbal@dtu.dk (Mattia Baldini)
}

\begin{abstract}
The Paris Agreement highlighted that pathways towards a future with fossil fuel independent societies require the transformation of all sectors to reduce the levels of greenhouse gasses emissions. To this end the industry sector, characterised by a high share of emissions and an intense and diversified energy demand, holds a paramount role. In the framework of assessing the transformation of the industry sector towards more sustainable alternatives, due to interdependencies within an energy system, the adoption of measures to reduce fossil fuel use in industry (e.g. efficiency, fuel substitution, electrification and energy cascading) can influence the operation and transformation of the energy system. To this end, the study proposes a method to simulate and optimise operational aspects of the industry sector at high level of details. The conceptual model is then integrated in an established bottom-up energy system model, creating a benchmark for analyses that can focus simultaneously on the impact of changes in the industry and in the energy sector on a system wide scale. On the practical side, by mean of a Danish case study, the paper sheds light on particular characteristics of the industry sectors, focusing on the structure of industrial energy use in regards to end-use processes, aspects of energy consumption, and measures for fossil fuel reduction. Considerations sparking from the analysis show the potential applicability of energy cascading, electrification and fuel substitution for industrial processes, engaging elements and technologies interlinked within the energy system. Given the theoretical approach proposed, similar considerations can be investigated for other case studies, exploiting the simultaneous optimisation of power, district heat, industry dispatches and characteristics. In this framework, the transformation of the energy use in industry sector can be simulated according to more stringent policies capping $\mathrm{CO}_{2}$ emission levels and specific support schemes, paving the way for carbon neutral societies and a more sustainable, yet resilient, future energy system.
\end{abstract}

Keywords: industry modelling, energy savings, fuel substitution, electrification, integrated energy system model Balmorel, process heat

\section{Introduction}

In light of the recent Paris Agreement, which highlighted the importance of decreasing the use of fossil fuels in energy intensive sectors for greenhouse gasses (GHG) emissions reduction purposes, the necessity to aim at carbon neutral societies and switch to $100 \%$ renewable energy systems is a clear goal. In Europe, similarly to other international contexts, two sectors stand out for substantial energy consumption and related GHG emissions: power and industry. In the last years the power sector has experienced a considerable transformation, with multiple interventions designed to shift primary sources of energy production towards more sustainable alternatives. Policies implemented and innovations have thus fostered renewable technologies, energy efficiency and sustainable fuels, reducing considerably the energy-production related GHG levels. Compared to the ongoing transformation in the power sector, measures for reducing GHG emissions in industry lags. With more than $125 \mathrm{TWh}$ of electricity consumption, $851 \mathrm{TWh}$ of fossil fuels used for energetic purposes and $671 \mathrm{TWh}$ of fossil fuels feedstock, in 2010 the industry sector accounted for almost $25 \%$ of the total final energy consumption in the European Union (EU) (Eurostat, 2017a). The related GHGs corresponded to $9 \%$ of the total EU28 emissions stock, as both European statistic institution (Eurostat, 2017b) and researchers confirms (Lechtenbohmer et al., 2016). The need for action to reduce fossil fuels in industry is clear, but several barriers exist. One essential difficulty is the heterogeneity of the sector, given the diversity of processes involved and a worldwide variation in facilities. Furthermore trade exposure, cost sensitivity, and long lived facilities have contributed to a slow adoption rate of interventions to reduce industrial emissions (Bataille et al., 2018). 
Three main established technology options to reduce industrial emissions are available: efficiency, fuel substitution and electrification. Energy cascading - that is, the use of high quality heat from a source to be reused for other processes or for general heating - can also be considered. These measures are also referred as "decarbonization lite" (Bataille et al., 2018), even though the true meaning of the word can be discussed, as some options (e.g. biomethane) actually include carbon. Applied examples of electrification (Lechtenbohmer et al., 2016), energy efficiency (Li and Tao, 2017) and fuel substitution (Rehfeldt et al., 2018) show successful application of these options to reduce industry related GHG emissions; furthermore, other studies focusing on future implementation of electrification (IRENA, 2014) and fuel substitution (International Energy Agency, 2012), forecast an intensive use of these measures for future scenarios.

Due to the interdependencies within an energy system, the adoption of measures to reduce fossil fuel use in industry influence the operation and transformation of the energy system. Intuitively, an increased electrification of industrial processes leads to an increase of the electricity demand that, consequently, implies changes in the operation of the energy system (e.g. transmission, power plant operation and investments). Similarly, energy efficiency might lower the need for fuels and electricity; energy cascading can result in similar impacts, potentially providing heat to other sectors in the form of district heat. Regarding fuel substitution, the need for gas and especially renewable gasses in industrial processes, correlates to the options to produce (biogas upgrading) and deliver (gas infrastructure) these gasses by the overall system. hence, when considering interventions to reduce industrial emissions, it is paramount to study the impact, benefits or challenges on an energy system. Given the current state of industry modelling in existing bottom-up energy system models, this is not always possible.

Models of this type often represent and simulate industry in an aggregate way, neglecting the complexity of the different industry branches or the structure of the processes with regard to input fuels and potentials to abate emissions. Other relevant details, such as temperature heat levels, fuel use characteristics and temporal profiles of energy consumption, are also mostly disregarded.

Consequently, analyses based on these models can sometimes fail to report correctly the impacts of changes in the industry sector and can lead to misleading results, both in terms of policy design and energy system operation and planning.

Our study is thus motivated by the following research questions. Which aspects characterise the unique structure of the industry industry sector, in terms of fuel use, processes and characteristics about temporal energy consumption? How can we adequately model such an heterogeneous sector and integrate it in established bottom-up energy system models? How can this conceptual model be used to perform reliable and thorough analyses on GHG emission mitigation measures in the industrial sector?

To address these research questions, we select the energy system model Balmorel (Ravn, 2017) and, within this framework, we propose a conceptual model to represent the industrial sector. To apply the method we focus on Denmark, an European country that is striving to find solutions to reduce GHG emissions, aiming at a fossil independent future in 2050, focusing intensively on the industry sector (Danish Energy Agency, 2017). Applied cases on a local scale show the convenience of reducing fossil fuels use through energy cascade (Bühler et al., 2017), electrification (Danish Energy Agency, 2014a), energy efficiency interventions (Buhler et al., 2016) and fuel substitution (Jensen et al., 2017). Although the studies indicate promising possibilities, none of the investigations considered a system wide context of changes in the industry sector. To this end, we consider Denmark as a case study. This paper contributes to the field by developing novel methods, useful to draw practical findings for researchers, industrial institutions and policy makers. On the methodological side, the contribution of the paper consists of (i) proposing a detailed conceptual model of the industry sector and (ii) integrate such model in an established energy system model, creating a benchmark for analyses that can focus simultaneously on the impact of changes in the industry (e.g. energy efficiency, electrification, fuel substitution) and in the energy sector (e.g. renewables, energy efficiency) on a system wide scale. On the practical side, by mean of the case study, the paper sheds light on particular characteristics of the industry.

By providing a detailed conceptual model of the industry sector considering structure of the processes with regard to input fuels, temporal profiles of energy consumption and options to reduce fossil fuels use, the paper narrows the knowledge gap on modelling and representation of the industrial sector in 
bottom-up energy system models.

The remainder of the paper is structured as follows. In Section 2, we present the current status of industry modelling in bottom-up energy system models. In Section 3, we present the methods developed. In Section 4, we introduce the case study and in Section 5 we discuss implications from the study. We conclude in Section 6, highlighting the relevant findings and suggesting future research.

\section{Literature review}

When investigating the impact of energy-related interventions in diverse sectors of the energy system (e.g. household, industry, services, etc..), it is fundamental to use tools that consider details such as the fluctuating component of energy production and consumption, given the evermore increasing share of renewable energy sources in the recent energy systems. To this end bottom-up energy system models, including technological explicitness and detailed temporal variation, are the most suitable tools for the task (Herbst et al., 2012).

The literature proposes a variety of bottom-up models suitable for different analyses, with characteristics varying according to the focus (Connolly et al., 2010) or the geographical target (Hall and Buckley, 2016). Among the existing models, only a few consider the industry sector. Moreover, the level of details considered varies, in regard to disaggregated energy consumption, fuel types, temporal profiles of demand and interaction within the energy system. Some models, among others EnergyPLAN (Aalborg University, 2018) and E4cast (Syed and Penney, 2011), consider the industry as an aggregated sector, with demand data defined on an annual level (TWh per year) with no hourly distribution. Also, the energy model MiniCAM operates on a very aggregated level, without representing specific technologies, but rather considering broad classes of technologies aggregated by sector (transportation, buildings, industry) and secondary fuel-type (liquids, gas, coal, biomass, electricity, hydrogen) (Brenkert et al., 2003). Oppositely, models like ESME (ETI), consider more details about the industry, including use of energy in industry segmented into various sectors (Iron, Steel and non-ferrous metals; chemicals; metal products, machinery and equipment; food, drinks and tobacco; paper printing and publishing; cements, ceramics, glass and lime; refineries; agriculture and other industry) and generic categories of production processes (High and low temperature process, drying and separation, motors, space heating and other) (Heaton, 2014).

Although different models feature different characteristics with more or less depth, to our knowledge, none of the existing bottom-up energy system models represents the industry sector in a great level of details, in regard to input fuels, temporal profiles of energy consumption, end-use and tailored options to reduce the use of fossil fuels.

Therefore, compared to previous models, in this study we propose an enhanced version of industry modelling, focusing on detailed characteristics of the sector while still considering the connections to the electricity and heat supply system. First, we propose an extension of an existing energy system model to include industry as a disaggregated sector. After, by mean of the study case, we shed light on the 'black box' of industry, proposing insights on the energy consumption in different branches by fuel and end-use or on the temporal variation of energy consumption at an hourly rate.

\section{Methods}

\subsection{Balmorel: energy system model}

Among the tools available in the literature (Connolly et al., 2010), the energy system model Balmorel is adopted for the analysis (Ravn, 2017). Balmorel is an open source, mostly linear energy system model that optimises investments and operation of power plants, storage devices and transmission lines for geographical areas that can be defined by the user (Wiese et al., 2018). The model considers a set of neighbouring countries operating in an interconnected electricity market (e.g. Germany, Sweden, Norway, Denmark, Finland). Each country is composed by one or several regions, among which electricity can be traded and transmitted, with limits imposed by given transmission capacity. Each electricity region is then divided into several district heating areas (DH); heat transmission among such areas is not allowed.

Balmorel considers time according to years, seasons (often applied for weeks) and individual time 
units (often applied for hours); the time horizon and time resolution are selected according to the requirements of the analysis.

The model relies on a set of exogenous input data, including existing capacities of electricity and heat generation technologies, transmissions lines and heat and power demand. Energy generating technologies include back-pressure and extraction combined heat and power plants (CHP), heat pumps, storage devices (for electricity and heat), and renewable based production technologies (hydro, wind, solar). Additional key assumptions on fuel prices, $\mathrm{CO}_{2}$ costs, taxes and support schemes can also be specified.

The model allows to simulate scenarios where demand and supply of electricity and heat are balanced. Operation and investments are optimised considering local generation vs. import/export, demand price elasticity and other characteristics typical of energy systems (Münster et al., 2012). For the simulations, Balmorel considers various "operation modes" with different functionalities. In one mode, the model finds economically efficient dispatches of an existing set of technologies; in another mode, the model has the possibility to dispatch energy using the existing set of technologies but also investing in new technologies and decommission the old asset. In the last mode, the model considers both operation modes (i.e. dispatch and investments) and includes the possibility to simulate different consecutive years (often referred as "rolling horizon"). The choice of the simulation mode varies according to the focus of the analyses, thus allowing to optimise (i) the operation of an existing and defined power system or (ii) dispatches and investment of existing and new power plants, for future energy system. When investing in a new technology, the model considers the discounted investment costs, based on lifetime and discount rate.

The model is supplemented with several addons that allow for specific investigations (Wiese et al., 2018) and has been previously applied for a wide range of studies, such as integration of renewable technologies in the energy mix (Ball et al., 2007), analysis of market conditions (Jensen and Meibom, 2008), policies implementation (Karlsson and Meibom, 2008), future role of district heating (Münster et al., 2012) and impact of energy efficiency technologies in the energy system (Baldini and Trivella, 2017).

\subsection{Modelling of the industry sector}

\subsubsection{Novel approach}

The current version of the energy system model Balmorel considers the industrial energy consumption only as a part of the overall electricity and district heat demand, without specifying absolute values or assigning hourly profiles of consumption. The model does not differentiate diverse industrial demands, meaning that details about input fuels and process heat demands are not considered. Such configuration does not allow specific analyses targeting detailed processes in the industrial sector. To this end, the structure proposed in Figure 1 represents a novel approach, with a clear split of the diverse industrial demands. The concept is versatile and flexible to be adapted for diverse industry branches (e.g. manufacture, agriculture, ...).

Figure 1: Schematic of industry sector representation in Balmorel

The novel approach considers details about the electricity demand of different industrial end-uses, facilitating the investigation of tailored end-use specific options (e.g. savings) aiming at reduce the use of fossil fuels. Electricity can be either supplied by the grid, or it can be self-produced in on-site industrial plants. Electricity is also used to run heat pumps, either to satisfy the heat demand, or to boost the quality of heat for specific processes.

Heat, originally considered only as district heat demand, now includes three temperature levels: space heating, process heat low temperature and process heat high temperature (See Table 3 for specifics). Heat, from district heating (DH) or excess heat, can be upgraded (i.e. the temperature is increased) using appropriate heat pumps. This means that one could use: (i) excess heat from a high temperature process directly or through a heat pump for district heat and low temperature process, (ii) excess heat from a high temperature process to preheat (partly heat) the heat input for high and low temperature process (depending on the temperature considered for low and high temperature processes) and (iii) heat from district heating to provide heat to a low temperature process (via heat pump). The use of excess heat for district heat or district heat for supplying process heat is limited to cases where a $\mathrm{DH}$ 
network is available (i.e. industrial process in proximity to a $\mathrm{DH}$ grid).

Fuels, for energy or feedstock purposes, are considered as input for energy conversion technologies in the industrial structure. Each technology is designed to run mainly with a distinct fuel, although it can potentially shift the input according to constraints imposed in the model (e.g. limitation on process emissions, taxes on carbon based fuels or fuel upgrade, for example from natural gas to biogas). This specific facilitates the investigation of $\mathrm{CO}_{2}$ reduction options for the industrial sector.

\subsubsection{Mathematical model}

The integration of the industry sector impacts the different constraints of the energy system model, according to the novel structure proposed. Hence, the mathematical formulation presented should be considered as an extension of the base mathematical model developed for Balmorel (Ravn, 2017). Table 1 reports the variables and parameters used in the modelling.

Table 1: Nomenclature for the industry modelling: parameters (upper part) and variables (lower part)

\begin{tabular}{|c|c|l|}
\hline Name & Unit & Description \\
\hline$C_{a f}^{f u e l}$ & $€ / \mathrm{GJ}$ & Fuel price \\
\hline$C_{a g}^{O \& M}$ & $€ / \mathrm{MWh}$ & Operation and maintenance costs \\
\hline$C_{a g}^{\text {inv }}$ & $€ / \mathrm{MW}$ & Investment costs \\
\hline$\Lambda_{c}$ & - & Annuity \\
\hline$C_{a g}^{\text {tax-inv }}$ & $€ / \mathrm{MW}$ & Tax on investment costs \\
\hline$E_{g}^{C O_{2}}$ & $\mathrm{~kg} / \mathrm{GJ}$ & CO ${ }_{2}$ emission coefficient \\
\hline$C_{c}^{\text {tax-CO}}$ & $€ / \mathrm{kg}$ & Tax on $C \mathrm{O}_{2}$ emissions \\
\hline$C_{f c}^{\text {tax-fuel }}$ & $€ / \mathrm{GJ}$ & Tax on fuel consumed \\
\hline$C_{a g}^{\text {tax }- \text { gen- ph }}$ & $€ / \mathrm{GJ}$ & Tax on heat process generation units \\
\hline$C_{a s t, u s}^{\text {up-step }}$ & $€ / \mathrm{MWh}$ & Cost of reduced consumption \\
\hline$C_{a s t, d s}^{\text {down-step }}$ & $€ / \mathrm{MWh}$ & Cost of increased consumption \\
\hline$C^{\text {infs }}$ & $€$ & Infeasibility penalty \\
\hline$D e_{r s t}^{\text {ind }}$ & $\mathrm{MWh}$ & Industrial electricity demand \\
\hline$D e_{r s t}^{\text {res }}$ & $\mathrm{MWh}$ & Residual electricity demand \\
\hline$D e_{r s t l}^{\text {ind }-e l m}$ & $\mathrm{MWh}$ & Industrial electricity demand by element \\
\hline$C O P_{g b}$ & - & Coefficient of performance \\
\hline$D h_{a s t}^{\text {res }}$ & $\mathrm{MWh}$ & Residual district heat demand \\
\hline$P h_{a s t b}$ & $\mathrm{MWh}$ & Industrial process heat demand \\
\hline
\end{tabular}




\begin{tabular}{|c|c|l|}
\hline$Q_{a g}^{p h}$ & MW & Capacity installed of process heat technology \\
\hline$F_{g}^{e f f}$ & - & Fuel efficiency \\
\hline$F_{c f}^{M A X}$ & GJ & Maximum fuel consumption per country \\
\hline$L I M_{c}^{C O_{2}}$ & $\mathrm{~kg}$ & Maximum $C O_{2}$ emissions per country \\
\hline$q_{a g s t b}^{p h}$ & $\mathrm{MWh}$ & Process heat generation \\
\hline$q_{a g b}^{\text {ph-new }}$ & $\mathrm{MW}$ & New capacity installed \\
\hline$f_{a g s t b}^{\text {rate }}$ & $\mathrm{MWh}$ & Fuel consumption rate \\
\hline$\Delta_{\text {ast,low }}^{\text {low }}$ & $\mathrm{MWh}$ & Slack variable lower bound \\
\hline$\Delta_{\text {ast,up }}^{\text {up }}$ & $\mathrm{MWh}$ & Slack variable upper bound \\
\hline$p_{a g s t}$ & $\mathrm{MWh}$ & Electricity generation \\
\hline$q_{a g s t}^{\text {DH }}$ & $\mathrm{MWh}$ & District heat generation \\
\hline$q_{a g s t b, d s}^{\text {ph-flex }}$ & $\mathrm{MWh}$ & Flexible process heat demand, down steps \\
\hline$q_{a g s t b, u s}^{\text {ph-flex }}$ & $\mathrm{MWh}$ & Flexible process heat demand, up steps \\
\hline
\end{tabular}

Objective function. In Balmorel, the value of the objective function reflect the total cost faced by the system to satisfy the energy demand, while complying with the constraints imposed. The costs included in the objective function vary according to the "optimisation mode" selected, ranging from costs of only dispatch to costs of both dispatch and investments. In both modes, the total costs includes considerations about transmission, taxes and emission pricing. hence, the value of the objective function can be interpreted as the least-cost solution to satisfy the energy demand, operating an asset available and (if considered) investing in new technologies.

To be consistent with the structure of the model, all industry-related costs (i.e. both operation and investments) are added to the main objective function. The costs include fuel consumption during the year (Eq. 1), O\&M of process heat technologies (Eq. 2), investment in new technologies (Eq. 3), taxes on investments (Eq. 4), taxes on emissions (Eq. 5), taxes on fuel consumption (Eq. 6), taxes on production of process heat (Eq. 7) and eventual changes in consumers' utility relative to process heat consumption (Eq. 8, Eq. 9). Slack variables are added for detecting infeasibilities (Eq. 10).

As the goal of the model is to satisfy the energy demand according to the least-cost combination, including Eq. 1-Eq. 10 to the objective function in Balmorel guarantees that all costs related with industrial energy consumption are part of the optimisation process.

$$
\begin{aligned}
& +\sum_{a, g, f, s, t, b} C_{a f}^{f u e l} 3.6 q_{a g s t b}^{p h} \\
& +\sum_{a, g, s, t, b} C_{a g}^{o \& M} q_{a g s t b}^{p h} \\
& +\sum_{a, g, c, b} q_{a g b}^{p h-n e w} C_{a g}^{i n v} \Lambda_{c}
\end{aligned}
$$




$$
\begin{aligned}
& +\sum_{a, g, c, b} q_{a g b}^{p h-n e w} C_{a g b}^{t a x-i n v} \Lambda_{c} 10^{6} \\
& +\sum_{a, g, c, s, t, b} E_{g}^{\mathrm{CO}_{2}} 3.6 f_{a g s t b}^{\text {rate }} C_{c}^{\text {tax }-\mathrm{CO}_{2}} \\
& +\sum_{a, g, c, s, t, f, b} C_{f c}^{\text {tax-fuel }} 3.6 f_{a g s t b}^{\text {rate }} \\
& +\sum_{a, g, s, t, b} C_{a g}^{\text {tax-gen-ph}} 3.6 q_{a g s t b}^{p h} \\
& +\sum_{a, s, t d o w n-s t e p} \sum_{a s t, d s}^{p h-f l e x} C_{a s t, d s}^{\text {down-step }} \\
& -\sum_{a, s, t u p-s t e p} q_{a s t, u s}^{p h-f l e x} C_{a s t, u s}^{u p-s t e p} \\
& +\sum_{a, s, t}\left(\Delta_{a s t, l o w}^{\text {low }}+\Delta_{\text {ast }, \text { up }}^{u p}\right) C^{\text {infs }}
\end{aligned}
$$

According to the logic of the model, the equations are considered for each area $a$, with the energy producing technologies $g$ and fuels $f$ available, during the seasons $s$ and time steps $t$ simulated. The index $b$ represents the different temperature levels of process heat, namely space heat (SH), process heat low (PHL) and process heat high temperature (PHH). The indexes us and $d s$ represent the up and down steps in the elasticity demand, while the indexes low and up refer to the upper and lower bounds when considering infeasibilities for the equations.

Electricity balance. As illustrated in Figure 1, the industrial electricity consumption $D e_{r s t}^{\text {ind }}$ related with a region $r$ is added to the electricity balance equation in Balmorel according to Eq. 11,

$$
\sum_{g} p_{a g s t}=D e_{r s t}^{r e s}+D e_{r s t}^{i n d}
$$

where $D e_{r s t}^{r e s}$ is the hourly profile of electricity demand not related with industry (residual).

The demand in the industry sector can be satisfied with electricity from the grid or self-production ( $p_{g}, \forall g \in G^{\text {ind }}$ ) and is related with the use of heat pumps (HP) and processes/end-uses

$$
\begin{aligned}
& \left(D e_{l}^{\text {ind-elm }}, \forall l \in L=\{\text { heatpump, processes }\}\right) \text { : } \\
& \sum_{l} D e_{r s t l}^{\text {ind }-e l m}=D e_{r s t}^{\text {ind }} .
\end{aligned}
$$

The heat pumps generate heat for the different temperature levels and are related with the electricity use according to Eq. 13,

$$
D e_{r s t, H P}^{\text {ind }- \text { elm }}=q_{a g s t b}^{p h} / C O P_{g b} \text {. }
$$

where $q_{a g s t b}^{p h}$ is the heat generated from the heat pumps suitable for the temperature levels (SH, PHL, $\mathrm{PHH})$, and $C O P_{g b}$ is the coefficient of performance.

District heating balance. With the addition proposed, the total energy system district heat balance now considers also the space heat demand for industrial purposes provided by the district heating network $P h_{a s t b}$ with $b=S H$. The technologies $g$ producing heat satisfy the total district heat demand: 
$\sum_{g} q_{a g s t}^{D H}=D h_{a s t}^{r e s}+P h_{a s t b}$

where $D h_{\text {ast }}^{\text {res }}$ is the hourly profile of the residual energy system district heat demand, not related with industry.

Process heat balance. As presented in Figure 1, the process heat demand is fulfilled with a different set of technologies $g$ : district heating grid, self production and other processes for space heating (set $G^{\text {ind-SH }}$ ); heat pumps and industrial processes for low and high temperature process heat (sets $G^{\text {ind }-P H L}, G^{\text {ind-PHH }}$ ). Eq. 15 imposes that, at every time step, the production from a set of different technologies meets the process heat demand at the temperature level proposed $(b \in B=\{S H, P H L, P H H\})$. Additional variables $\left(q_{a g s t b, d s}^{p h}, q_{a g s t b, u s}^{p h}\right)$ allow flexibility in the demand (up and down), while slack variables $\Delta_{\text {ast,low }}^{\text {low }}, \Delta_{\text {ast,up }}^{u p}$ are inserted for modelling purposes.

$$
\begin{aligned}
& \sum_{g} q_{a g s t b}^{p h}=P h_{a s t b}-\sum_{\text {down-step }} q_{a g s t b, d s}^{p h-f l e x} \\
& +\sum_{\text {up-step }} q_{a g s t b, u s}^{p h-f l e x}-\Delta_{a s t, l o w}^{\text {low }}+\Delta_{\text {ast }, \text { up }}^{\text {up }}
\end{aligned}
$$

Process heat technologies related constraints. Additional constrains are introduced to reflect technical functioning of the process heat technologies. The fuel consumption rate is fixed by Eq. 16, where $F_{g}^{\text {eff }}$ is the fuel efficiency of technology $g$. Eq. 17 imposes limits on the production, i.e. at any time production $q_{a g s t b}^{p h}$ can exceed capacity $Q_{a g}^{p h}$.

$$
\begin{aligned}
& f_{a g s t b}^{r a t e}=q_{a g s t b}^{p h} / F_{g}^{e f f} \\
& q_{a g s t b}^{p h} \leq Q_{a g}^{p h}
\end{aligned}
$$

Eq. 18 and Eq. 19 impose a cap on fuel consumption $\left(F_{c f}^{M A X}\right)$ and $C_{2}$ emissions ( $\operatorname{LIM}_{c}^{\mathrm{CO}_{2}}$ ) from process heat production per country. The same constraint in Eq. 19 can be used to cap $\mathrm{NO}_{x}$ and $\mathrm{SO}_{2}$ emission. The equations can be used to investigate the industrial energy mix while complying with future goals on emission reduction and fuel substitution.

$$
\begin{gathered}
\sum_{g, s, t, b} 3.6 f_{a g s t b}^{\text {rate }} \leq F_{c f}^{M A X} \\
\sum_{a c g s t b} E_{g}^{\mathrm{CO}_{2}} 3.6 f_{\text {agstb }}^{\text {rate }} \leq L I M_{c}^{C O_{2}}
\end{gathered}
$$

\subsection{Modelling of fossil fuel reduction options}

From a modelling point of view, the addition of options to reduce fossil fuels for industry influences the optimisation in different ways.

The electrification of the industry implies a shift from fossil fuel to electricity-based processes.

Modelling wise, this means that a new set of process-heat technologies $g$, based solely on electricity $f$ $\in \mathrm{F}=\{$ Electricity $\}$, competes with the existing fuel-based technologies (See Eq. 15 and Eq. 16). The criteria for the competition can be economic (e.g. the cheapest option for the system, based on Eq. 1 Eq. 10), environmental (e.g. cap on $\mathrm{CO}_{2}$ emission, see Eq. 19), or policy based (e.g. imposing a share of electrified industrial processes in future energy systems, see Eq. 18). Given the constraints imposed, the model then decides the optimal level of investments and operation of the technologies in 
the energy system.

The same method applies for the fuel substitution when investigating the potential use of renewable gasses, biomass and biogas. For this option, the model can change the fuel input in existing technologies from the fuels currently in use to more renewable options.

Energy cascading (or excess heat) can be considered a free source of heat for the processes. As a preliminary approach, 'blocks of energy' are thus made available for processes at different temperature levels, acting as free energy in Eq. 15 to satisfy the process heat demand. As the availability of excess heat sources is related to the geographical location of the source (being e.g. an industry or a district heat network), the energy made available must be linked with the geographical limitation of the modelling framework (i.e. excess heat from an industry can be used in a DH network only if it is in proximity). Recent findings from studies on Danish industrial excess heat sources (Bühler et al., 2017), identification of cases for excess heat utilisation using GIS (Bühler et al., 2018b) and spatio-temporal analysis of industrial excess heat as resource for district heating (Bühler et al., 2018a), show that detailed data about excess heat can be determined in relation to the location of the process heat demand.

Energy savings in the industrial sector have a direct effect on process heat and industrial electricity demand. Based on the method proposed by Baldini and Trivella (2017), the savings can be added as a complementary option. The model has the choice to either supply the energy demand (both electricity and process heat) with the current set of technologies or to invest in energy saving measures, that lower energy needs. The optimisation process selects the option that minimise the total costs, while complying with the restrictions. Estimates on the cost of energy saving measures are available from the Danish Energy Agency (2015) and are presented in Table 5, aggregated by end-use. In case the costs are not discounted, the model should include considerations about lifetime and discount rate. Investments in energy saving measures impact Eq. 1 - Eq. 10 for the investment costs and Eq. 11, Eq. 14, Eq. 15 for the reduction on electricity, DH and process heat demand. The investment depends on the value of the savings achieved during the lifetime versus the cost of the corresponding energy demand.

\subsection{Data processing}

With the intention of unifying various data sources to have a clear, detailed, and up-to-date dataset about industrial energy consumption, we perform data processing. In regard to the case study considered, the approach used in data gathering and analysis first considers details about fuel consumption by sector and end-uses. The Danish version of the international nomenclatures NACE ${ }^{1}$ (Rev. 2, ISIC, Rev. 4) is the Dansk Branchekode DB07 (Danish Industry Classification 2007), a statistical classification of economic activities that categorises each enterprise based on its main activity. The energy consumption by industry group and fuel type is published by Statistics Denmark on a yearly basis (Statistics Denmark, 2017). The data are available according to the industry structure based on the db117-grouping, a national classification that organises Danish companies based on their Danish Branchcode (DB07) into 117 activity groups. This structure is widely applied by Danish institutions for identifying the affiliation of companies (Danish Energy Agency, 2014b) and is often used in other national data sources, for example about conversion potential in industry (Danish Gas Technology Center, 2013a).

With the intention of unifying data from different sources, we used the details provided in Sørensen and Petersen (2015) from the year 2012 to link more recent data (Statistics Denmark, 2017). The first study provides detailed figures on end-use for 57 sectors, based on 22 end-use processes and 20 type of fuels, for the year 2012. On the other hand, Statistics Denmark only provides data about energy use by fuel and industry group for more recent years. To unify the sources and provide details for recent years (e.g. 2015 or 2016), we calculate a "end-use factor" from the relative share of fuel consumption by end-use for each industry group in the year 2012. Afterwards, we apply the "relative end-use factor" to more recent data from Statistics Denmark. As the format of the industry groups and some fuel naming conventions slightly differ in the two sources, these have to be correlated and aligned. The coupling of these data is one of the required data processing steps illustrated in Figure 2, which also reports the whole data processing flow for the study.

\footnotetext{
${ }^{1}$ Statistical classification of economic activities in the European Community
} 
Figure 2: Data processing from original sources to input for Balmorel.

Another relevant step in the data handling regards the task of linking the location of industrial demand with excess heat sources and district heating networks, according to the geography of the energy system model. To this end, we perform a geo-location of: (i) the three types of heat demand (space, low temperature and high temperature), (ii) the industrial electricity demand and (iii) heat supply potential from a district heating $(\mathrm{DH})$ network for industrial heat demand.

The geographical boundaries used for mapping the industrial energy consumption follow the logic of Balmorel and differ between heat and electricity. For electricity, the model considers "regional boundaries", meaning that all electricity demand in one region is grouped together. For Denmark, the model considers two regions (Denmark East and Denmark West), where the first includes the island of Zealand and the second includes Jutland and the island of Funen. On the other hand, the heat demands are linked with the district heating networks, as district heating is the most used source for the "space heating" end-use demand (See subsection 4.2). Following Petrovic and Karlsson (2014), we consider 36 areas as an aggregation of the Danish district heating networks (Agency for Data Supply and Efficiency, 2017a), publicly available as shape-files (Erhvervsstyrelsen, 2017). Other small-scale networks in rural areas are aggregated in two fictional DH areas for the eastern and western part of Denmark. To locate the industries with DH networks, we use the list of companies located in Denmark, which includes addresses, affiliation to detailed industry group and number of employees information (Virk, 2017). The geographic coordinates of the companies are derived by matching the addresses to an address list containing coordinates (Agency for Data Supply and Efficiency, 2017b) using Python. Via the coordinate information, the companies are assigned to the 36 areas with a "spatial join operation" with the QGIS software (QGIS, 2017).

Once the industries are assigned to an area, the next task is to link the total industrial energy consumption with the unique industry. The method to locate the industrial energy demand by fuel and end-use is based on the employee shares per industrial groups (i.e. $\mathrm{MWh} / \mathrm{year}$ per employee), a method already used in previous studies (Bühler et al., 2017). One recurrent issue in the method is that the number of employees is usually not proportional to the energy used, if considering companies from different industry groups. Meaning that an energy intensive group like service will have more employees per MWh/year than a production facility with high automation. However, the higher the level of details in the distinction between industry groups, the more similar the employee/energy ratio of the companies within the respective industry group. Considering the 57 industry groups used, the level of detail is sufficient to assume the number of employees to be proportional with the energy use in the respective industry group. As Figure 2 illustrates we calculate, for each company, the share of employees in relation to the sum of employees in the respective industry group. Subsequently, the yearly energy demand by fuel and end-use for each industry group is distributed to the companies according to the employee share. Based on the geo-location of the industries within an area, we obtain the process heat demand by fuel and end-use for each area and we locate the potential for heat supply from a DH network according to the three temperature levels defined. The industrial regional electricity demand is calculated with the same method.

\section{Case study: Characteristics of the Danish industry sector}

Relevant features characterising the industry sector range from sectoral classification to specific aspects about energy use, geo-location of consumption and potentials for fossil fuel reduction. As the intention is to provide a case description and a method that can be replicated for different study cases, open source data are used almost entirely throughout the study; confidential data are presented in aggregated form. To this end, we consider Denmark as a case study. The description of details characterising the Danish case constitutes the bases for the case study: with an overview about enduse processes, related fuel consumption and temporal profiles of consumption, the industry sector can be conveniently integrated in an energy system model according to the method proposed.

\subsection{Structure of the Danish Industry}

In the literature, industry is the term that refers to a variety of processes characterised by high energy intensity and use. As the term does not have a standard definition, the processes considered to represent the industrial sector vary from study to study, making similar analyses on the field difficult 
to compare. Buhler et al. (2016) shows that results derived from a broader approach provide additional insights and a stronger reliability, compared to other studies which considered a restricted number of processes and industries when assessing energy consumption (e.g. in the U.S. (AlGhandoor et al., 2010) or in Iran (Sanaei et al., 2012)). To this end, in this study we include agriculture, manufacturing and services in the term industry and industry sector. On the other hand, we exclude from the analysis transportation, both as branch and as end-use within the industry sector; hence, any energy use or emission balance related with transportation of industry feedstock and products is not part of the study.

Sørensen and Petersen (2015) proposes a data analysis about energy use in Danish industry, providing indications about the yearly energy demand in 2012 for 57 different sectors (excluding refinery, public service and construction), according to 20 fuel types and 22 end-uses. Details about the distribution of fuels amongst the end-uses are also provided.

To deal with the heterogeneity of the industry sector and to ease the illustration of the data available, in this case study we cluster the 57 industrial sectors in five groups according to similarities in temporal pattern of energy consumption: agriculture, production single shift, production double shift, production triple shift and services. The underlying assumptions behind the classification are based on Wiese and Baldini (2017), while the detailed classification of production industry groups can be found in the supplementary material.

The temporal pattern of energy consumption is different for each of the five categories. The consumption in agriculture, including gardening and horticulture, follows a pattern linked to seasonal activities, with lower energy use during summer and higher during fall and winter. Throughout the week, the consumption is higher during the day (working hours from 6 to 18) and week days and lower by night and in the weekend.

For services, the energy consumption is higher during daytime and weekdays, and lower during the nights and weekend, representing activities mostly conducted during normal working hours. The energy consumption is mostly constant throughout the year, apart from energy for space heating purposes that follows a seasonal pattern.

The production group includes manufacturing and extraction processes. The subdivision in single, double and triple shift is linked to the weekly schedule of activities. Single shift facilities typically operate during normal average working hours in the week days (e.g. 8 to 17) and are closed during weekends/holidays; double shift have longer operating hours (about 15 hours a day), they close during the night and often during weekends/holidays; triple shift facilities run as continuous production (i.e. almost constant consumption throughout the year) and close down only few times a year. Sectors belonging to this group often present a steady base-load consumption for processes such as auxiliaries or ovens.

\subsection{Energy in the Danish industry}

Figure 3 illustrates the total energy use for the Danish industry sector, gathered according to groups proposed, for the year 2012. The industry's energy use accounts for $\sim 156 \mathrm{PJ}$, distributed among production $(\sim 88 \mathrm{PJ})$, service $(\sim 48 \mathrm{PJ})$ and agriculture $(\sim 19 \mathrm{PJ})$. In the production sector, double $(50 \%)$ and triple shift (44\%) cover a significant higher share compared to the single shift group $(6 \%)$.

Figure 3: Total energy use for the Danish industry sector, excluding transport, by fuel (Sørensen and Petersen, 2015).

The fuel consumption is distributed unevenly among the sectors, with electricity $(36 \%)$, natural gas $(21 \%)$, district heating $(15 \%)$, gasoil/kerosene $(6.4 \%)$ and petroleum coke $(4 \%)$ covering the majority of the consumption, while the other fuels contribute to a minor extent.

Figure 4, Figure 5 and Figure 6 show how, within the sectors, the fuels are used for different end-uses.

Figure 4: Breakdown of energy consumption by end-use and fuel in agriculture (Sørensen and Petersen, 2015). 
The heat maps, presented in three clustered groups, provide an indication on the most energyintensive processes in connection with the most employed fuels. In agriculture, most of the fuel consumption is related to processes heating up to $150^{\circ} \mathrm{C}(51 \%)$. Although the category includes different temperature levels of heat demands, most of the consumption is related with warming greenhouses for horticulture purposes. The temperature required for such uses is around $20-25^{\circ} \mathrm{C}$ (Johansson and Rizzo, 2008), so heat from district heating networks can be used as a direct input, as the supply temperatures from district heating networks are in the range of $70-90^{\circ} \mathrm{C}$.

Figure 5: Breakdown of energy consumption by end-use and fuel in production (Sørensen and Petersen, 2015).

Figure 6: Breakdown of energy consumption by end-use and fuel in services (Sørensen and Petersen, 2015).

In the production sector, processes such as drying (15\%), heating/boiling $(16 \%)$ and space heating $(11 \%)$ are predominant, while in service, space heating (50\%) and lightning $(17 \%)$ together consume more than half of the total fuels.

Regarding the fuel use, the production sector presents a high diversity of fuels employed for various end-uses, with natural gas and electricity (31\% each) standing out. Electricity $(50 \%)$ and district heating (37\%) dominate the total energy use in the service sector, while electricity (34\%) and gasoil/kerosene $(25 \%)$ are predominant in agriculture.

\subsubsection{Energy use by industry groups and fuels}

Based on the data processing presented in the methodology, Table 2 shows the resulting values for years subsequent to 2012. The values highlight a drop in the total fuel use to $\sim 148$ PJ in 2014 , followed by a raise to $\sim 152 \mathrm{PJ}$ and $\sim 154 \mathrm{PJ}$ in 2015 and 2016. Analysing the macro changes for the industry groups during the period 2012-2016 reported in Table 2, one can notice that the energy use in agriculture does not change significantly. Service, after a decrease until 2014, increased again until 2016, almost to similar levels as 2012 ( 48 PJ). For production, the single and double shift group present a pattern similar to service, with double shift group eventually having greater consumption in 2016 compared to 2012 levels. Triple shift group presents a more stable trend around 37 PJ.

Table 2: Sum of fuel consumption [PJ] in the aggregated industry groups for different years. Own calculations based on Statistics Denmark (2017).

\begin{tabular}{|l|c|c|c|c|c|}
\hline Industry group & 2012 & 2013 & 2014 & 2015 & 2016 \\
\hline Agriculture & 19.3 & 19.4 & 18.4 & 18.6 & 18.5 \\
\hline Service & 52.3 & 49.9 & 46.4 & 47.6 & 49.7 \\
\hline Production single shift & 5.1 & 4.8 & 4.6 & 5.6 & 4.9 \\
\hline Production double shift & 42.8 & 41.7 & 41.3 & 42.6 & 43.2 \\
\hline Production triple shift & 38.6 & 37.0 & 37.7 & 37.9 & 38.1 \\
\hline Total & 158.1 & 152.8 & 148.4 & 152.3 & 154.4 \\
\hline
\end{tabular}

\subsubsection{Heat levels}

According to the heat classification proposed in the methodology, Table 3 presents the end-uses according to temperature levels of the heat demand: space heat, process heat low and process heat high temperature.

Table 3: Clustering end-use by heat level. Process heat levels from Sørensen and Petersen (2015)

\begin{tabular}{|l|c|l|}
\hline End-use & Temperature level $\left[{ }^{\circ} \mathrm{C}\right]$ & Model heat type \\
\hline Space heating & $50-90$ & space heat \\
\hline
\end{tabular}




\begin{tabular}{|l|c|l|}
\hline Distillation & $50-100$ & process low \\
\hline Heating/Boiling & $70-110$ & process low \\
\hline Drying & $\sim 100$ & process low \\
\hline Inspissation & 130 & process low \\
\hline Burning/Sintering & $\geq 250$ & process high \\
\hline Melting/Casting & $\geq 300$ & process high \\
\hline
\end{tabular}

Once again, according to the methods proposed, we use the relative end-use shares from 2012 (Sørensen and Petersen, 2015) to link more recent data sources and calculate the end-use fuel consumption for 2013-2016 based on the yearly data on fuel use by industry group (Statistics Denmark, 2017). Table 4 displays the trends of consumption by end-use, for the period 2012-2016.

Table 4: Sum of fuel consumption [PJ] by end-use in the aggregated industry groups for different years. Own calculations based on Sørensen and Petersen (2015); Statistics Denmark (2017).

\begin{tabular}{|l|c|c|c|c|c|}
\hline End-use & 2012 & 2013 & 2014 & 2015 & 2016 \\
\hline Electricity & 52.0 & 51.6 & 52.9 & 54 & 52.1 \\
\hline Heat Pump & 0.6 & 0.7 & 0.7 & 0.7 & 0.6 \\
\hline Losses & 8.1 & 7.5 & 6.8 & 7 & 7.3 \\
\hline Process Heat High & 12.6 & 12.4 & 13.1 & 13.2 & 13.6 \\
\hline Process Heat Low & 47.3 & 44.4 & 42.8 & 43.5 & 44.6 \\
\hline Space Heat & 37.5 & 36.2 & 32.1 & 33.9 & 36.2 \\
\hline Total & 158.1 & 152.8 & 148.4 & 152.3 & 154.4 \\
\hline
\end{tabular}

\subsubsection{Consumption profiles}

Details about temporal variations of industrial electricity and heat consumption are necessary, while investigating the impact of changes in consumption on a system wide scale. The aggregated industry groups introduced (agriculture, service, production single, double, triple shift) are characterised by different temporal patterns. Furthermore, temporal profile of consumption differ significantly according to the purpose: fuel consumption for process heat and electricity are process dependent, while fuel consumption for space heat is linked to a strong seasonal pattern. Relevant considerations about these insights are also discussed in Wiese and Baldini (2017).

As Figure 5 and other studies show that natural gas is the most employed fuel for process-heat purposes in Danish industry (Wiese and Baldini, 2017), in this study we use temporal patterns of natural gas consumption, for the year 2016, to derive the heat demand profiles for space and process heat consumption (Dansk Gas Distribution, 2016). Due to confidentiality, we present the profiles aggregated according to the categorisation proposed. Sectoral profiles of hourly electricity consumption are collected from Andersen et al. (2013a, b).

Figure 7 and Figure 8 present details about temporal pattern of electricity consumption on a yearly scale.

Electricity. Figure 7 presents the profiles in terms of boxplots, where the size of each box relate with the range of variation in the profiles: the larger the box, the larger the yearly variation. The biggest range of variations within the profiles occurs for agriculture and production single shift, highlighting a seasonal consumption profile related to farming activities for the former and a considerable variation in weekdays, weekends and holidays activities for the latter. For the production category, the size of the boxplots decreases in size 
for higher number of production shifts (i.e. the triple shift shows the smallest box) suggesting a lower range of variation of the profiles for these categories.

Figure 7: Boxplots of relative electricity consumption. Own calculations based on Energinet.dk (2017); NordPoolSpot (2018); Elforbrugs Panelerne (2018); Andersen et al. (2013a, b); Sørensen and Petersen (2015).

Figure 8 shows the development of the temporal patterns of electricity consumption throughout the year. The greatest seasonal variation occurs for agriculture. Moreover, service, production single and double shift present a decreased consumption in correspondence with summer holidays, while production triple shift shows a rather constant profile during the year.

Figure 8: Relative variation of seasonal electricity consumption, trend-lines (fit to the 18th order). Own calculations based on Energinet.dk (2017); NordPoolSpot (2018); Elforbrugs Panelerne (2018); Andersen et al. (2013a, b); Sørensen and Petersen (2015).

Fuel consumption for space heat purpose. The profiles in Figure 9 and Figure 10 show the fuel consumption for space heat purpose in industry, on a yearly and a weekly scale. Figure 9 gives an indication of the seasonal variation, with a higher consumption by fall and winter, compared to spring and summer levels. Some drops occur during the year, probably related with changes in weather conditions that required a lower use of fuels for space heating. Although following similar trends, the profiles differ from each other. The triple shift production stands out during the summer with higher levels of consumption compared to other categories, exception made for August.

Figure 9: Hourly profile of fuel consumption for space heat purposes in one year. Own calculations based on Dansk Gas Distribution (2016); Sørensen and Petersen (2015).

A similar trend is highlighted in Figure 10, which shows that, on weekly basis, the triple shift production group has the smallest variation, indicating a range of processes with a continuous consumption.

Figure 10: Hourly profile of fuel consumption for space heat purposes in one week. Own calculations based on Dansk Gas Distribution (2016); Sørensen and Petersen (2015).

Fuel consumption for process heat purpose. The yearly profiles of fuel consumption for process heat purposes in Figure 11 highlight the relevant impact of holidays on the demand, as the consumption is significantly lower during holidays such as Easter, summer and Christmas. Differently from fuel consumption for space heating, the profiles show the link with the working schedule, with a clear weekly variation in the consumption throughout the year. Also, exception made for the holidays, production single shift shows the largest variation, while the triple shift category the smallest.

Figure 11: Hourly profile of fuel consumption for process heat purposes in one year. Own calculations based on Dansk Gas Distribution (2016); Sørensen and Petersen (2015).

Figure 12 confirm the trend on a weekly scale, highlighting that processes of triple shift barely reduce their energy consumption in the week ends, making them a potential candidates for interventions of fossil fuel reduction.

Figure 12: Hourly profile of fuel consumption for process heat purposes in one week. Own calculations based on Dansk Gas Distribution (2016); Sørensen and Petersen (2015); Wiese and Baldini (2017). The division the sectoral groups is based on Wiese and Baldini (2017) while the division into share of end-use of fuel on Sørensen and Petersen (2015).

\subsubsection{Geographical mapping of industrial energy consumption}

In a context of interrelation between commodities (e.g. heat sources, district heating networks, combined heat and power production) and particularly for cases of potential applicability of energy cascading (i.e. re-utilisation of excess heat for different purposes), it is essential to consider the 
geographical location of industrial energy demand. In the case of Denmark, district heating plays a major role, with approximately $60 \%$ of the Danish heating demand supplied via district heat networks and $40 \%$ of fuel used for DH purposes based on renewable sources (Münster et al., 2012). An increased use of district heat for space heat purposes - linked with an higher share of renewable sources as primary input in the production - represents a relevant option to reduce the use of fossil fuel in the future industry. The feasibility of this option depends on the location of the industrial demand as, intuitively, the heat source can be used by an industry only if it is on the proximity of a district heating area. As highlighted in the methodology, similar considerations applies for energy cascading cases such as: (i) using district heat for process heat purposes in heat pumps to boost the quality of the heat and adapt it to the temperature needed (Buhler et al., 2016) or (ii) using excess heat from industrial processes in district heating networks.

According to the approach proposed in subsection 3.4, we locate the potential for heat supply from a DH network according to the three temperature levels defined. The resulting space heat demand within district heat areas sums up to $\sim 17 \mathrm{PJ}$ of which $\sim 11 \mathrm{PJ}$ are already supplied by district heat; $\sim 16 \mathrm{PJ}$ of space heat demand were found to be located out of existing district heat areas. Figure 13 illustrates the share of space heat demand supplied by district heat for the 36 areas considered. The share per area ranges from 40 to $80 \%$.

Figure 13: Share of space heat demand of companies supplied by district heat. Own calculations based on Agency for Data Supply and Efficiency (2017a); Virk (2017); Bühler et al. (2018a); Petrovic and Karlsson (2014); Sørensen and Petersen (2015); Statistics Denmark (2017).

Regarding process heat at low temperature, about $10 \mathrm{PJ}$ are located within district heat areas and $~ 33$ PJ outside. Of this total, the share already supplied by district heat ranges between 0 and $30 \%$ for the different areas, as Figure 14 shows.

For process heat at high temperature, the analysis indicates that about $3 \mathrm{PJ}$ are located within the current district heat areas, while $\sim 10 \mathrm{PJ}$ are located outside; a possible source of excess heat that could be used for district heating purposes.

Figure 14: Share of low process heat demand supplied by district heat. Own calculations based on Agency for Data Supply and Efficiency (2017a); Virk (2017); Bühler et al. (2018a); Petrovic and Karlsson (2014); Sørensen and Petersen (2015); Statistics Denmark (2017).

\subsection{Potentials for fossil fuel reduction options}

In relation to the analysis of different end-uses and the insights on the geographical analysis, we summarise different fossil fuels reduction options in industry for electricity, space heat, process heat low and high temperature purposes. Table 5 proposes estimates and considerations for all industry groups, based on different sources. According to energy audits performed in most of the Danish industries, the Danish Energy Agency (2015) reports that the potential for energy savings in industry amounts to about $39 \mathrm{PJ}$, with most of the savings being available for electricity $(46 \%)$ and heat low temperature $(39 \%)$ processes. The potential, reported for a maximum pay back time of 10 years, considers improvements in end-use processes, with cross-cutting technologies in process integration, electric motors and transmission and automation as main pillars. As end-uses vary in size and numbers across the industry types, the values are gathered by electricity and heat levels for the whole industry sector; in case of need, they can be tailored according to the level of details required, e.g. for different industry branches.

Table 5: Overview of fossil fuels reduction options for industrial purposes (sources are provided in the footnotes).

\begin{tabular}{|l|l|l|l|l|}
\hline Category & Space heat & Process heat low & Process heat high & Electricity \\
\hline Energy savings $^{2}$ & & & & \\
\hline & $5.2[\mathrm{PJ} /$ year $]$ & $15.6[\mathrm{PJ} /$ year $]$ & $0.4[\mathrm{PJ} /$ year $]$ & $18.3[\mathrm{PJ} /$ year $]$ \\
\hline
\end{tabular}

${ }^{2}$ Danish Energy Agency (2015) 


\begin{tabular}{|l|l|l|l|l|}
\hline $\begin{array}{l}\text { Excess heat } \\
\text { potential }\end{array}$ & $4.9[\mathrm{PJ} /$ year $]$ & limited & NA \\
\hline Electrification & Heat pump (HP) & $\begin{array}{l}\text { HP/year] } \\
\sim 88 \% \text { techn. } \\
\text { convertible }\end{array}$ & $\begin{array}{l}\text { Electric heat; } \\
\sim 25 \% \text { techn. } \\
\text { convertible }\end{array}$ & NA \\
\hline $\begin{array}{l}\text { Biomass } \mathrm{DK}^{5}: 75- \\
315[\mathrm{PJ} / \text { year }]\end{array}$ & Applicable & Applicable & Limited & $\begin{array}{l}\text { Main energy } \\
\text { system }\end{array}$ \\
\hline $\begin{array}{l}\text { Biogas DK }{ }^{6}: 35- \\
170[\mathrm{PJ} / \text { year }]\end{array}$ & $\begin{array}{l}\text { Restricted by } \\
\text { location; } \sim 10 \\
{[€ / \mathrm{GJ}]^{7}}\end{array}$ & $\begin{array}{l}\text { Restricted by } \\
\text { location and } \\
\text { application }\end{array}$ & NA & $\begin{array}{l}\text { Main energy } \\
\text { system }\end{array}$ \\
\hline Renewable gas & $12-18[€ / \mathrm{GJ}]$ & $12-18[€ / \mathrm{GJ}]$ & $12-18[€ / \mathrm{GJ}]$ & $\begin{array}{l}\text { Decided on } \\
\text { system level }\end{array}$ \\
\hline
\end{tabular}

Regarding excess heat potentials, recent studies on a Danish context conclude that 8.5 PJ of accessible industrial excess heat could supply up to $4.9 \mathrm{PJ}$ of the current district heat demand each year (Bühler et al., 2017). Of this amount, only $36 \%$ of the excess heat would require a heat pump to raise the temperature for district heating purposes $\left(\sim 70-80^{\circ} \mathrm{C}\right)$. Similar studies, about spatio-temporal and economic analysis of industrial excess heat (Bühler et al., 2018a) and GIS-based case studies on excess heat (Bühler et al., 2018b), also report details about excess heat by district heat area, temperature range and industry group, highlighting a potential of $4.9 \mathrm{PJ}$ for process heat low temperature purposes, using heat pumps to boost the heat temperatures. Similar considerations do not pertain high temperature processes, as the amount of energy consumption necessary to elevate the quality of heat from district heat levels to the required temperatures, would make the case non convenient.

On the premises of an energy system highly based on renewable production, electrification is also a viable option to reduce fossil fuel use for all three process heat categories. For the case of Denmark, the Danish Energy Agency (2014b) and the Danish Gas Technology Center (2013a) assess the share of electrification potential for different processes and technology types, suggesting $88 \%$ for process low temperature, and $25 \%$ for process high temperature. The application for space heat and for low heat temperature processes imply the use of heat pumps as a complementary option, using ground or ambient temperature differences to generate heat. Preliminary indications show that a significant part of the industrial space heat can be supplied by heat pumps, as this technology has become commercially available and more economically convenient (Energinet.dk, 2015). Applied cases also show the practicality of using excess heat to this end, using heat pumps (Kortegaard Støchkel et al., 2017). The case is different for processes at low temperature heat. Supply of process heat of up to $150^{\circ} \mathrm{C}$ from either excess heat or district heat in combination with a heat pump is technical possible, but the economic feasibility highly depends on the supply and the demand temperature; the higher the difference, the lower the coefficient of performance (COP) and thus the higher the required electricity share. Also, generally electrification is straightforward for processes requiring heat radiation, however there are exceptions. For processes highly based on gas use (e.g. in slaughterhouses, production of oil, fat, milk products, thickening substances like pektin), direct change to electricity is not as straightforward as for radiation. According to industrial facilities, a more detailed analysis of the circumstances and the temperatures would be required to define the applicability for each case (Danish Gas Technology Center, 2013a). Electrification for process heat high temperature, using heat pumps, is more challenging as, due to the high temperatures required, heat pumps are not suitable tools for the task. For this category, some processes are thus directly electrified. The low rate of

\footnotetext{
${ }^{3}$ Bühler et al. $(2017,2018 \mathrm{a})$

${ }^{4}$ Danish Energy Agency (2014b); Danish Gas Technology Center (2013a)

${ }^{5}$ EA Energy Analysis and University of Southern Denmark (2016)

${ }^{6}$ EA Energy Analysis and University of Southern Denmark (2016)

${ }^{7}$ Jensen and Skovsgaard (2017)

${ }^{8}$ Ea Energy Analysis (2017); Jensen and Skovsgaard (2017)
} 
conversion for process heat high temperature is also related with processes requiring flames (e.g. glass fibre production) that cannot be directly electrified, exception made for some few processes where electricity could potentially substitute the flames (e.g. where the heat is transferred by radiation and the flue gas does not directly get in contact with the process material).

Regarding biomass, a meta-study concludes that the potential for biomass in Denmark ranges between 75-315 PJ/year (EA Energy Analysis and University of Southern Denmark, 2016). Biomass can be used as a fuel to power various processes generating heat at different temperatures. However, the applicability for high temperature processes is limited, as the low heating value of the biomass would require a higher amount of fuel input, compared to other sources.

Biomass and electricity could in total replace up to $78-85 \%$ of the current natural gas use in industry. For most appliances, the costs for the biomass option seems to be higher than electrification, even when including electricity grid connection or enforcement costs (Danish Gas Technology Center, 2013b).

Solid or liquid organic resources can also be used as a source to derive biogas, with a potential applicability about 35-170 PJ/year (EA Energy Analysis and University of Southern Denmark, 2016). However, as other sectors than industry will require biomass and biogas for various uses, the price of these commodities might increase. Additionally, the use of most of these bio-based commodities is restricted regionally, due to the high transport costs that some kinds of biomass require (e.g. manure).

Raw biogas represents another opportunity to replace highly carbon based fuels for industry purposes. Although it cannot be used directly in most of the existing gas appliances due to its composition, it can be converted to similar fuels, as the main composition (methane and $\mathrm{CO}_{2}$ ) is similar to natural gas. For example, raw biogas from anaerobic digestion or thermal gasification can be upgraded by removing the $\mathrm{CO}_{2}$; otherwise the $\mathrm{CO}_{2}$-component can be transformed to methane, adding hydrogen.

Biogas can then be used for appliances currently using natural gas, reducing significantly the $\mathrm{CO}_{2}$ emissions. Studies on thermal gasification in the Danish energy system (Ea Energy Analysis, 2017) and on the impact of CO2-costs on biogas usage (Jensen and Skovsgaard, 2017) estimate the biomass price around $12-18 € / \mathrm{GJ}$.

\section{Discussion}

In the context of assessing the role of industry in the future energy system, the study first develops a conceptual model for the industry sector in an integrated energy system model and then presents a description of the specific aspects of industrial consumption, in terms of end-uses input fuels, temporal profiles of energy consumption and options to reduce fossil fuels use.

The conceptual model for the industry sector is developed in the framework of an integrated energy system model, providing a tool that can be used as benchmark to test the impact of fossil-fuel reduction options on a system wide scale. The introduction of a high level of detail allows tailored analyses, such as resilience of future configuration of energy system when the industry will electrify part of its processes. Also, the details provided about the sectoral fuel consumption facilitate the investigation on the potential (application and effect) for fossil fuel reduction in future configuration of the industry sector, given the upcoming targets of fossil fuel reduction policies. The modelling of the fossil fuel reduction options, integrated within the model proposed, can lead to considerations about the qualitative and quantitative configuration for a system transformation, allowing the measures to compete on economic (Eq. 1-Eq. 10) and environmental terms (Eq. 19). To this end, elements such as generation mix in the electricity and heat supply, electricity prices and future targets are decisive. Eq. 10 can provide considerations about the contribution of each heat process technology in the future of industry, as well as the role of heat pumps, which are expected to take over in different end-uses.

The methodology developed can be applied to investigate tailored research questions, exploiting the simultaneous optimisation of power, district heat and industry dispatches and characteristics. Among other, the model can investigate on the role of biomass and biogass for sectors and end-uses, on the convenient use of renewable gasses, on the uptake of electrification in the long run considering 
renewable based energy systems and on the flexibility that electrified industrial heat and electricity demand could provide to the rest of the system.

The theoretical approach proposed can be potentially used for other case studies, particularly for countries that share a similar structure in terms of energy system (e.g. high share of district heat and possibility for energy cascading). Furthermore, as the energy system model Balmorel considers a set of different countries (e.g. Germany, Finland, Sweden, Norway), a similar analysis of the industrial sector can be performed in any of those countries with the same model, given data availability. The applied case of Denmark is selected because of intensive data availability. On European level, Eurostat provides data on fuel usage and emission by sector, which are more aggregated than the presented Danish data, but could be nonetheless used for the modelling approach described in the study (Eurostat, 2017a). Open source data about fuel use by end-use in industry, as well as geographical level of detail about addresses and company locations, are more difficult to retrieve elsewhere. Being aware of the difficulties to gather industrial data, throughout the report we report details about the structure of the Danish sector and the various sources for the data, so that other analyses can similarly adapt the data sources for the need, emulating the study.

In relation to the modelling framework proposed, the investigation on the characteristics of the industry sector on the applied Danish case, has highlighted the following key points.

Electricity, natural gas and district heating dominate the total industrial energy consumption, while the relevance of consumption by end-use varies according to the sector considered. Processes heating up to $150^{\circ} \mathrm{C}(51 \%)$ dominate in agriculture, space heating $(50 \%)$ and lightning $(17 \%)$ in service while the production sectors is more diversified, including drying (15\%), heating/boiling (16\%) and space heating (11\%). This opens the bases for the possible transformation of the sector, as most of the enduses, currently using fossil fuels, can be replaced with cleaner alternatives. In particular, heat pumps and energy cascading cover a relevant role, given the high share of heat demand of lower temperatures among the end-uses.

The temporal profiles presented stress the importance of using real data instead of constructed profiles, indicating situations that are particularly useful for studies on energy systems, such as drops in energy demand, seasonality of the profiles or weekly schedules. Given the rising share of fluctuating energy sources in energy systems, realistic temporal consumption patterns becomes necessary in energy modelling, particularly in relation to demand occurrence and related flexibility. In this context, electrification is particularly relevant given its existing potential $(88 \%$ and $25 \%$ for low and high temperature processes) as it will enhance the industrial dependence from electricity use and, consequently, from the electricity generation sources of the energy system. Also, the analysis on the profiles highlights that process in the triple shift category are mostly constant throughout the year. Hence, interventions of fossil fuel reduction should target and prioritise these particular end-uses. Although the profiles are derived on the bases of data from different years, they are generally applicable for modelling the temporal variation of demand in the industry sector. In a short term horizon, it is likely that the absolute value of consumption slightly varies, but this should not affect the relative temporal development of the profiles, exception made for unforeseen events (e.g. country crisis, massive relocation of activities, etc.).

The process of mapping the industrial energy consumption shows the relevance of the high geographical resolution, particularly when dealing with interconnections between commodities (e.g. heat and electricity) and end-uses. The analysis indicates that 6 PJ of heat demand could be additionally supplied by district heat. For energy systems characterised by a high share of district heat, it is crucial to consider the proximity component between sources and consumers, as cases such as using excess heat in heat pumps for district heating and processes purpose can be relevant in the context of fossil fuel reduction in industry. These considerations might be less important for countries where district heat is not substantial, and would consequently reduce the requirements of geographical resolution of the input data.

The analysis of the options to reduce fossil fuels in industry has identified savings, energy cascading, electrification (heat pumps and direct electrification), biomass, biogas and renewable gas as viable options. In regard to process electrification, the potential applicability of heat pumps stands out as the most relevant option, because of its flexibility to combine the use of electricity to provide heat at different temperature levels. Given the importance and the interconnection within the energy system, it is paramount to distinguish technical properties and the coefficient of performance (COP) according 
on the application area when modelling heat pumps, as the performances are strictly dependent on the temperature levels. The fact that electrification is a viable option for space heat, process heat low, and even process heat high temperature strengthens the need to consider the industrial demand in relation to the rest of the electricity and heat system, combining temporal and geographical resolution, for an in-depth analysis of reducing fossil fuels in industry. Among the end-uses presented, space heat, low temperature and electricity based processes enjoy a widespread series of options to reduce their impact in terms of fossil fuels. In particular, savings and excess heat can potentially contribute up to $38 \mathrm{PJ}$ and 9 PJ respectively. Biomass (75-315 PJ), biogas (35-170 PJ) and renewable gas, available with a greater potential, can also represent a great opportunity for fossil fuel reduction, although they are limited in the application due to technical limits (e.g. adaptability to natural gas processes), geographical restriction or competing demands for the scarce bioenergy in the future.

\section{Conclusion}

In the framework of assessing the transformation of the industry sector towards more sustainable alternatives, it is paramount to consider the elements characterising the industry sector. Moreover, given the interdependencies between industry sector and energy system, the adoption of fossil-fuel reduction measures can influence the operation and transformation of the energy system. Considering the current state of industry modelling in existing bottom-up energy system models, it is currently not possible to assess such implications.

Focusing on an applied study case for Denmark, the study proposes a method to simulate and optimise operational aspects of the industry sector at high level of details. By providing a detailed conceptual model considering structure of the processes with regard to input fuels, temporal profiles of energy consumption and options to reduce fossil fuels use, the paper narrows the knowledge gap on modelling and representation of the industrial sector in bottom-up energy system models.

Considerations sparking from the structural analysis of the industry show the potential applicability of energy cascading, electrification and fuel substitution for industrial processes targeting end-uses currently based on gas and other fuels. Engaging elements and technologies interlinked within the energy system such as heat pumps, are proposed as solutions for transforming the industry sector. The integration of industry in an established energy system model, creates a benchmark for analyses that can focus simultaneously on the impact of changes in the industry and in the energy sector on a system wide scale. In this framework, the transformation of the energy use in industry sector can be simulated according to more stringent policies capping $\mathrm{CO}_{2}$ emission levels and specific support schemes, paving the way for carbon neutral societies and a more sustainable, yet resilient, future energy system.

\section{Acknowledgements}

The research has been co-financed by Innovation Fund Denmark under the research project SAVE-E (grant no. 4106-00009B) and the research project FUTURE GAS (grant no. 5160-00006B). The authors also thank the institutions which gave access to relevant data: the Danish Energy Agency (Energistyrelsen, DEA) and the energy consulting company Viegand Maagøe. This paper develops on work presented first at the $12^{\text {th }}$ SDEWES 17 Conference on sustainable development of energy, water and environment systems at Dubrovnik, Croatia.

\section{References}

Aalborg University, 2018. EnergyPLAN - Advanced energy systems analysis computer model.

Accessed on April 28, 2017.

URL http: / / www . energyplan.eu/

Agency for Data Supply and Efficiency, 2017a. Administrative Shapes (Kortforsyningen, in Danish).

Accessed on April 28, 2018.

URL https: / / download.kortforsyningen.dk/ 
Agency for Data Supply and Efficiency, 2017b. Adresses of Denmark. Accessed on April 28, 2018. URL http: //download.aws.dk/adresser \\#danmark

Al-Ghandoor, A., Phelan, P. E., Villalobos, R., Jaber, J. O., 2010. Energy and exergy utilizations of the U.S. manufacturing sector. Energy 35 (7), 3048-3065.

Andersen, F. M., Larsen, H. V., Boomsma, T. K., 2013a. Long-term forecasting of hourly electricity load: Identification of consumption profiles and segmentation of customers. Energy Conversion and Management 68, 244-252.

Andersen, F. M., Larsen, H. V., Gaardestrup, R. B., 2013b. Long term forecasting of hourly electricity consumption in local areas in Denmark. Applied Energy 110, 147-162.

Baldini, M., Trivella, A., 2017. Modeling of electricity savings in the Danish households sector: from the energy system to the end-user. Energy Efficiency, 1-19.

Ball, M., Wietschel, M., Rentz, O., 2007. Integration of a hydrogen economy into the German energy system: an optimising modelling approach. International Journal of Hydrogen Energy 32 (10-11), $1355-1368$.

Bataille, C., Åhman, M., Neuhoff, K., Nilsson, L. J., Fischedick, M., Lechtenböhmer, S., SolanoRodriquez, B., Denis-Ryan, A., Steiber, S., Waisman, H., Sartor, O., Rahbar, S., 2018. A review of technology and policy deep decarbonization pathway options for making energy-intensive industry production consistent with the Paris agreement. Journal of Cleaner Production 187, 960-973.

Brenkert, A., Kim, S., Smith, A., Pitcher, H., 2003. Model Documentation for the MiniCAM. Tech. rep., United States Department of Energy, accessed on April 18, 2018.

URL

https://www.pnnl.gov/main/publications/external/technical_reports/PN $\mathrm{NL}-14337 \cdot \mathrm{pdf}$

Buhler, F., Nguyen, T. V., Elmegaard, B., 2016. Energy and exergy analyses of the Danish industry sector. Applied Energy 184, 1447-1459.

Bühler, F., Petrovi, S., Holm, F. M., Karlsson, K., Elmegaard, B., 2018a. Spatiotemporal and economic analysis of industrial excess heat as a resource for district heating. Energy 151, $715-728$.

Bühler, F., Petrović, S., Karlsson, K., Elmegaard, B., 2017. Industrial excess heat for district heating in Denmark. Applied Energy 205 (August), 991-1001.

Bühler, F., Petrović, S., Ommen, T., Holm, F. M., Pieper, H., Elmegaard, B., 2018b. Identification and Evaluation of Cases for Excess Heat Utilisation using GIS. Energies, 1-24.

Connolly, D., Lund, H., Mathiesen, B., Leahy, M., 2010. A review of computer tools for analysing the integration of renewable energy into various energy systems. Applied Energy 87, 1059-1082. 
Danish Energy Agency, 2014a. Energy scenarios towards 2020, 2035, and 2050 (Energiscenarier frem mod 2020, 2035 og 2050, in Danish). Accessed on April 18, 2018.

URL

https://ens.dk/sites/ens.dk/files/Energiklimapolitik/energiscenarier -_analyse_2014_web.pdf

Danish Energy Agency, 2014b. The future use of the gas infrastructure (Den fremtidige anvendelse af gasinfrastrukturen, in Danish). Accessed on April 18, 2018.

URL

https://ens.dk/sites/ens.dk/files/EnergiKlimapolitik/gasinfrastruktu ren_-_analyse_2014_web.pdf

Danish Energy Agency, 2015. Identification of energy saving potential in Industry (Kortægning af energisparpotentialer i erhverslivet, in Danish). Accessed on April 18, 2018.

URL

https://ens.dk/sites/ens.dk/files/Energibesparelser/kortlaegning \_af \_energisparepotentialer\_i\_erhvervslivet.pdf

Danish Energy Agency, 2017. The energy commissions recommendations for Future Energy Policy (Energikommissionens anbefalinger til fremtidens energipolitik, in Danish). Accessed on April 18, 2018.

URL http://efkm.dk/temaer/energikommissionen/

Danish Gas Technology Center, 2013a. Analysis of gas consumption in Denmark's industry and industry - Characterisation and technical conversion potential (Analyse af gasforbruget i Danmarks erhverv og industri - Delrapport 1 Karakterisering og teknisk konverteringspotentiale, in Danish). Accessed on April 18, 2018.

URL http: //docplayer.dk/2771009-Analyse-af-gasforbruget-i-danmarkserhverv-og-industri.html

Danish Gas Technology Center, 2013b. Analysis of gas consumption in Denmark's industry and industry - Conversion costs (Analyse af gasforbruget i Danmarks erhverv og industri - Delrapport 2 Konverteringssomkostininger, in Danish).

Dansk Gas Distribution, 2016. Gas consumption profiles linked with DB07.

Ea Energy Analysis, 2017. Integration of thermal gasification into the Danish energy system (Integration af termisk forgasning i det danske energisystem, in Danish). Tech. rep., EA, accessed on April 18, 2018.

URL http: / /www.ea-energianalyse.dk/projectsdanish/1607_integration_af_termisk_forgasning_i_energisystemet.html 
EA Energy Analysis, University of Southern Denmark, 2016. Biogas and other EV fuels for heavy transport - Analysis of opportunities and challenges of phasing out (Biogas og andre VE brændstoffer til tung transport - Analyse af muligheder og udfordringer ved udfasning, in Danish). Tech. rep., EA, accessed on April 18, 2018.

URL

https://ens.dk/sites/ens.dk/files/Bioenergi/biogas_og_anden_ve_til_t ung_transport.pdf

Elforbrugs Panelerne, 2018. Data for hourly electricity consumption by customers. Accessed on March 1, 2017.

URL http://www.elforbrugspanel.dk/Pages/Rapportering.aspx

Energinet.dk, 2015. Energy Concept 2030. Accessed on April 18, 2018.

URL http: / / www . energinet.dk/DA/KLIMA-OG-

MILJOE/Energianalyser/Analyser/Fremtidens-Energi/Sider/default.aspx

Energinet.dk, 2017. Download of market data.

URL http://energinet.dk/EN/El/Engrosmarked/Udtraek-afmarkedsdata/Sider/default.aspx

Erhvervsstyrelsen, 2017. District heat supply areas (PlansystemDK: Forsyningomraade, in Danish). Accessed on April 18, 2018.

URL http://kort.plansystem.dk/spatialmap?

Eurostat, 2017a. Final energy consumption by sector. Accessed on April 6, 2018.

URL http://ec.europa.eu/eurostat/web/products-datasets/-/tsdpc320

Eurostat, 2017b. Greenhouse gas emissions by sector. Accessed on April 6, 2018.

URL http://ec.europa.eu/eurostat/web/products-datasets/-/tsdcc210

Hall, L. M., Buckley, A. R., 2016. A review of energy systems models in the UK: Prevalent usage and categorisation. Applied Energy 169, 607-628.

Heaton, C., 2014. Modelling Low-Carbon Energy System Designs with the ETI ESME Model. Tech. rep., Modelling, Energy Technologies Institute, accessed on April 18, 2018.

URL http://www.eti.co.uk/programmes/strategy/esme

Herbst, A., Toro, F., Reitze, F., Jochem, E., 2012. Introduction to energy systems modelling. Swiss journal of economics and statistics 148 (2), 111-135.

International Energy Agency, 2012. Energy Technology Perspectives 2012: Pathways to a Clean Energy System. Tech. rep., IEA, accessed on April 18, 2018.

URL 
https://www.iea.org/publications/freepublications/publication/ETP201

2_free.pdf

IRENA, 2014. Renewable Energy in Manufacturing: A technology roadmap for REmap 2030. Tech. Rep. June, IRENA, accessed on April 18, 2018.

URL http: //irena.org/remap/REmap_2030 RRenewable-Energy-inManufacturing $\cdot$ pdf

Jensen, I. G., Pisinger, D., Münster, M., 2017. Optimizing the supply chain of biomass and biogas for a single plant considering mass and energy losses. European Journal of Operational Research 262, $744-758$.

Jensen, I. G., Skovsgaard, L., 2017. The impact of CO2-costs on biogas usage. Energy 134, 289-300.

Jensen, S. G., Meibom, P., 2008. Investments in liberalised power markets. Gas turbine investment opportunities in the Nordic power system. International Journal of Electrical Power and Energy Systems 30 (2), 113-124.

Johansson, M., Rizzo, M., 2008. Mapping of business energy consumption (Kortlægning af erhvervslivets energiforbrug, in Danish). Tech. Rep. November, Dansk Energi Analyse AS and Viegand \& Maagøe ApS, accessed on April 18, 2018.

URL

http://www.dea.dk/images/stories/dea/rapporter/Kortlaegning_af_erhve rvslivets_energiforbrug_2008.pdf

Karlsson, K., Meibom, P., 2008. Optimal investment paths for future renewable based energy systems-Using the optimisation model Balmorel. International Journal of Hydrogen Energy 33 (7), $1777-1787$.

Kortegaard Støchkel, H., Lava Paaske, B., S. Clausen, K., 2017. Catalogue of large heat pump projects in the district heating system (Inspirationskatalog for store varmepumpeprojekter $\mathrm{i}$ fjernvarmesystemet, in Danish). Tech. rep., Danish Energy Agency and Grøn Energi, accessed on April 18, 2018.

URL

https://ens.dk/sites/ens.dk/files/Varme/inspirationskatalog_for_stor e_varmepumper.pdf

Lechtenbohmer, S., Nilsson, L. J., Aahman, M., Schneider, C., 2016. Decarbonising the energy intensive basic materials industry through electrification - Implications for future EU electricity demand. Energy 115, 1623-1631.

Li, M. J., Tao, W. Q., 2017. Review of methodologies and polices for evaluation of energy efficiency in high energy-consuming industry. Applied Energy 187, 203-215. 
Münster, M., Morthorst, P. E., Larsen, H. V., Bregnbæk, L., Werling, J., Lindboe, H. H., Ravn, H., 2012. The role of district heating in the future Danish energy system. Energy 48 (1), 47-55.

NordPoolSpot, 2018. Historical market data. Accessed on April 18, 2018.

URL http://www.nordpoolspot.com/historical-market-data/

Petrovic, S., Karlsson, K. B., 2014. Danish heat atlas as a support tool for energy system models. Energy Conversion and Management 87, 1063-1076.

QGIS, 2017. QGIS, A Free and Open Source Geographic Information System. Accessed on January 26, 2017.

URL https://www.qgis.org/en/site/

Ravn, H., 2017. Balmorel: energy system model.

URL http: / / www.balmorel.com

Rehfeldt, M., Fleiter, T., Worrell, E., 2018. Inter-fuel substitution in european industry: A random utility approach on industrial heat demand. Journal of Cleaner Production 187, $98-110$.

Sanaei, S. M., Furubayashi, T., Nakata, T., 2012. Assessment of energy utilization in Iran's industrial sector using energy and exergy analysis method. Applied Thermal Engineering 36 (1), 472-481.

Sørensen, L. H., Petersen, P. M., 2015. Survey of energy consumption in companies (Kortlægning af energiforbrug i virksomheder, in Danish). Accessed on April 18, 2018.

URL

https://ens.dk/sites/ens.dk/files/Energibesparelser/kortlaegning \_af $\backslash$ _energiforbrug \_i\_virksomheder.pdf

Statistics Denmark, 2017. ENE2HA: Energy Account in common units by use and type of energy. Accessed on April 18, 2018.

URL https: / / www.statbank.dk/ENE2HA

Syed, A., Penney, K., 2011. Australian energy projections to 2034 - 2035. Tech. rep., Department of Resources, Energy and Tourism, Camberra, accessed on April 18, 2018.

URL https: //industry.gov.au/Office-of-the-Chief-

Economist/Publications/Documents/aep/australianenergyprojections2034 -35 report.docx

Virk, 2017. Production Units Denmark (Dansk produktionsheder, in Danish). Accessed on April 18, 2018.

URL https://datacvr.virk.dk/data/cvr

Wiese, F., Baldini, M., 2017. Pathways to Carbon Neutral Industrial Sectors: Integrated Modelling Approach with High Level of Detail for End-use Processes. 12th Conference on Sustainable 
Development of Energy, Water, and Environment Systems, 1-14Accessed on April 18, 2018.

URL

http://orbit.dtu.dk/files/139267828/SDEWES2017\_0534\_WieseBaldini.p df

Wiese, F., Bramstoft, R., Koduvere, H., Alonso, A. P., Balyk, O., Kirkerud, J. G., Tveten, Å. G., Bolkesjø, T. F., Münster, M., Ravn, H., 2018. Balmorel open source energy system model. Energy Strategy Reviews 20, 26-34. 